\title{
The Influence of E-Banking Service for Customer Satisfaction
}

\author{
Adeh R. Komala ${ }^{1}$, I. Kusnanan ${ }^{2}$ \\ $\underline{\text { adehrkomala@email.unikom.ac.id }}{ }^{1}, \underline{\left.\text { imamkusnanan@mahasiswa.unikom.ac.id }{ }^{2}\right\}}$ \\ ${ }^{12}$ Departemen Akuntansi, Universitas Komputer Indonesia, Indonesia
}

\begin{abstract}
The purpose of this research is to find out how the influence of internet service has an impact on customer satisfaction. This study used a descriptive analysis method in BRI banking service to obtain facts from existing problems and find factual information. The results of the descriptive analysis study show that internet banking service affects the comfort, security, and customer satisfaction. Comfort is the most important aspect of the internet banking because customers can interact with banks easily without the need to come to the bank, and internet banking speeds up banking transactions so that it can increase bank customer loyalty. It can be concluded that E-banking internet service has a very significant effect on customer satisfaction.
\end{abstract}

Keywords: Customer, User, ID, Balance, Account,

\section{Introduction}

Computer technology has been widely applied in every aspect of our lives, such as in business, government, education, finance, and even health [1]. The manual pattern of traditional society slowly changes to an automation system that uses sophisticated technology in its business processes. This process of change is called Business Evolution, as stated by ES Soegoto in his book Menjadi Pembisnis Ulung, namely the process of occurring business activities from time 
to time according to the condition, technological, economic, social and cultural developments at present [2]. Technology and information have become the most important aspect of modern banking. The information has become the most valuable asset to be protected from insiders, outsiders, and competitors. The ability of a bank to take advantage of new opportunities often depends on its ability to provide open, accessible, available and safe network services. Having a good reputation for information security will increase market share and company profits. Therefore, banks must be responsible for fraudulent activities carried out through internet channels. Banks must refund most customers for losses, even though customers compromise their account credentials [3]. Indonesia's current population is 262 million people. Out of this amount, there are only $20 \%$ or 52 million of the population is served by banking services in Indonesia, and most of these people live in urban areas [4].

Research on the influence of the quality of e-banking services or internet banking on customer satisfaction has been done previously. The results of research conducted by Akbar \& Paryes stated that customer satisfaction has a mediating role between the quality of e-banking services to customer loyalty [5]. This result is also in line with previous research conducted by Akbar Sher, Som, Fazli, and Alzaidiyeen, who found that service quality may create high loyalty through customer satisfaction [6]. According to Agyapong and Ghana, it is stated that potentially customer satisfaction is very influential in customer loyalty [7]. The results of research conducted by Ni Made Savitri Anggaeni \& Ni Nyoman Kerti Yasa also stated that service quality has a very positive and significant effect on customer satisfaction in the use of internet banking services [8].

The purpose of this research is to find out how the influence of internet services on customer satisfaction by using descriptive analysis method at Bank Rakyat Indonesia (BRI) to obtain facts from existing problems and find factual information.

\section{Method}

This study used descriptive analysis method by describing the official website of Bank Rakyat Indonesia (BRI) internet banking to obtain facts about the satisfaction of bank customers from the problems that exist in the internet banking service and to find factual information through previous research related to the influence of the e-banking service on satisfaction for the customer. So that it could analyze what variables can influence customer satisfaction and how much influence e-banking services can get customer satisfaction loyalty.

\section{Results and Discussion}

Internet banking from BRI is a new way to conduct banking activities using an internet network that allows customers to be able to interact with Bank BRI wherever they are. All individual customers who have BRI saving accounts and have an ATM can use e-banking facilities by registering Bank BRI branches or can register directly through BRI ATMs. Registering the TOKEN at the BRI branch may be needed to support a financial transaction. As for noncustomers, they are required to open a savings account in the BRI branch to get the facility of the BRI e-banking service.

BRI internet banking service has facilities for customers, such as look at the account balance and mutation, transfer with the same bank (BRI) or other bank, pay bills namely Telkom Bill, BRI Credit Card, and PLN, as well as purchasing something, such as Cellular and Electronic 
Money Credit, Communication with Bank BRI Customer Service through the Internet Banking Inbox facility.

BRI internet banking is designed to prioritize the security of customers personal and financial information, BRI internet banking uses the International Internet Standard Security SSL 3.0 program with a 256-bit encryption system, the most sophisticated information scrambling system at this time so that customers' personal \& financial information cannot be read via the internet. The customer also gets a unique User ID \& Password, so that there is no duplication and only the owner can access internet banking. Every time the customer logging in, they are only allowed to repeat the wrong User ID \& Password 3 times before the access is blocked to prevent irresponsible misuse. Every transaction that is instructed will not be processed without confirmation and approval from the customer-owner itself, and also each transaction will be given a reference number that is used later if there is a question or a problem occurs related to the transaction. If there is no activity for 10 minutes, the system will automatically log-out the access from internet banking service to prevent unauthorized abuse.

This is in line with the results of previous research conducted by Shergill and Li (2005). This study proves that security in using internet banking services affects privacy and ethics. This result proves that users (customers) believe in internet banking if internet banking is based on ethical values, confidentiality, and high security [9]. Internet banking login view can be seen in Figure.1.

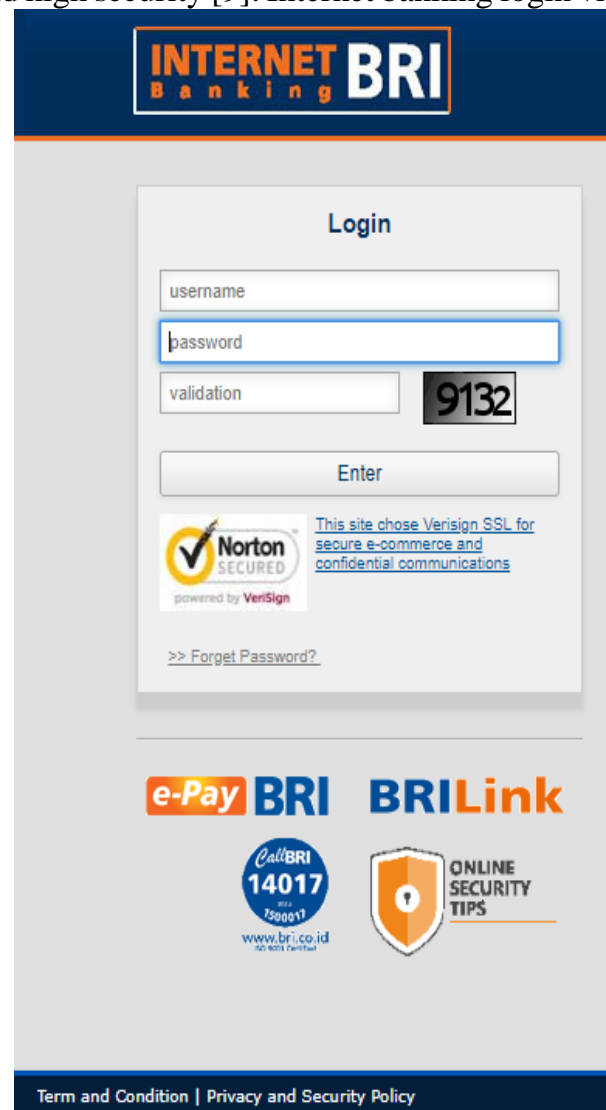

Fig. 1. Login. Figure was adopted from www.bri.co.id on Dec 10th,2018 
On the login page, we can use the account. We need to enter the internet banking site. On the home page, each menu and sub-menu on BRI internet banking is designed to be easier for customers to use. In the home menu, we can see the account information that we have. Figure 2

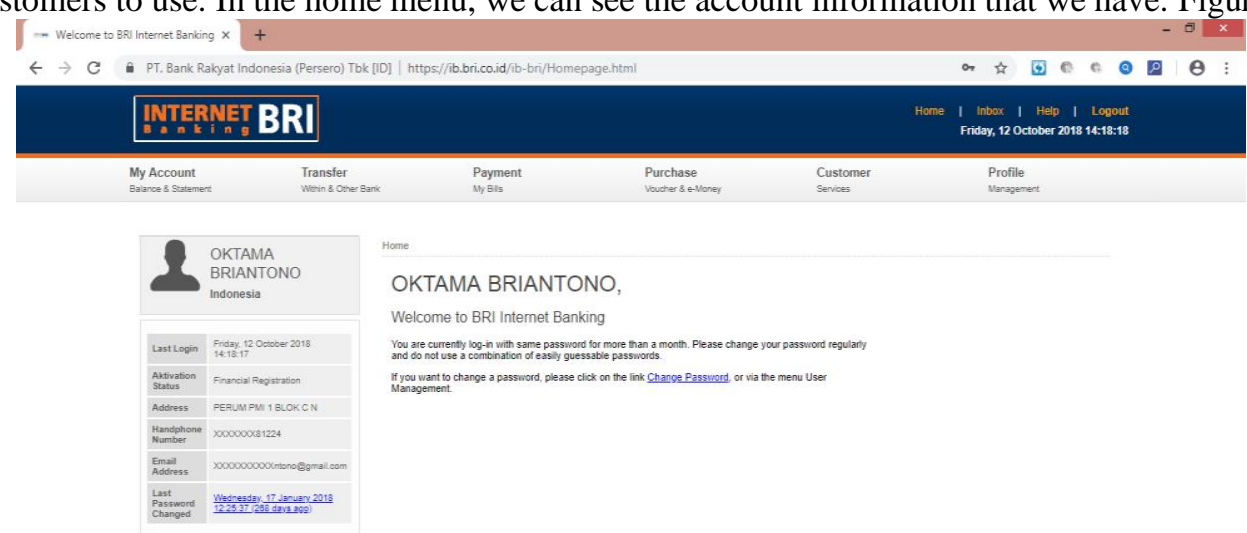

Fig. 2. Home. Figure was adapted from www.bri.co.id on Dec 10th,2018

The profile of the account owner will be displayed not specifically to remain secure. The system will notify the customer to immediately replace the account password if the account has not been replaced or still use the old password because changing the old password with a new one will avoid misuse of the e-banking account carried out by an unauthorized person. So, the system will make customers comfortable when using services from BRI internet banking. Customers can find out the remaining account balance in the My Account menu view. Figure 3

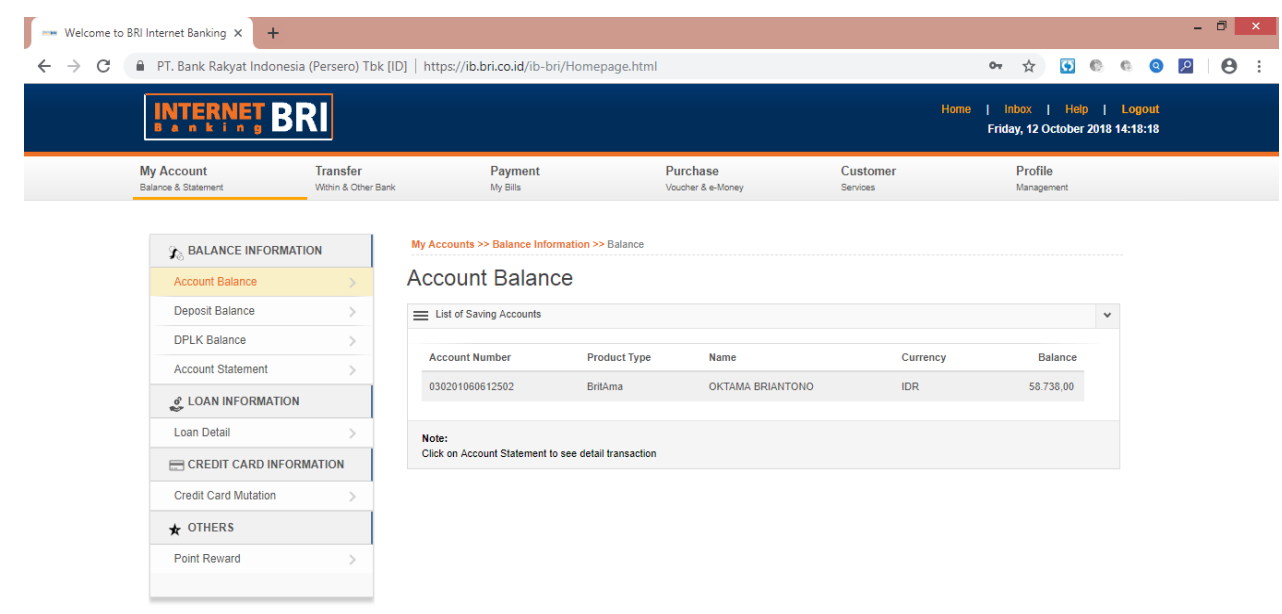

Fig. 3. My Account menu. Figure was adapted from www.bri.co.id on Dec 10th,2018 
Any changes in balances contained in BRI will be immediately updated into BRI internet banking, while for transferring funds within BRI or other bank accounts, or by bill payment through BRI internet banking, the transfer of funds the account balance will immediately change both at the Bank BRI system and BRI internet banking. In the transfer menu view, customers can transfer funds between their accounts, to another account within BRI by filling out the form on the transfer form Figure 4.

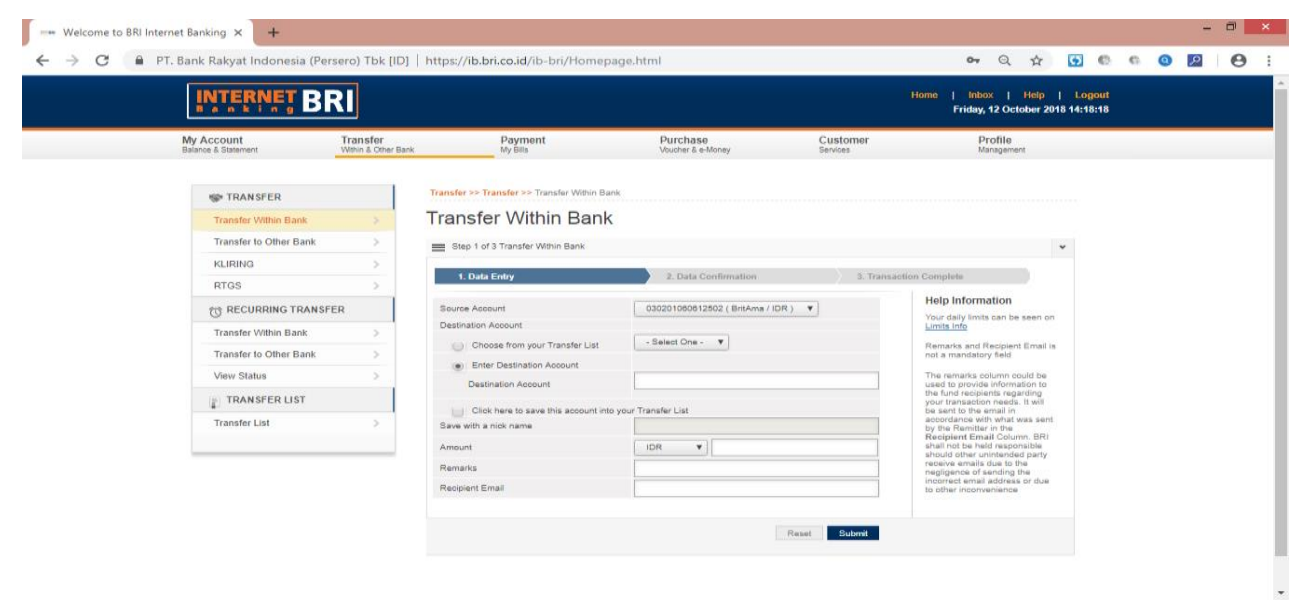

Fig. 4. Transfer Menu. Figure was adapted from www.bri.co.id on Dec 10th,2018

Instant balance account will change in a system when successful transfer confirmation is sent to the destination. For this type of transfer, the customer cannot change/cancel all transfer that has been made through the internet. Whereas for the type of transfer according to date and routine, if it is still in the last waiting status, then the customer can change/cancel the transfer. In the payment menu section, customers can pay bills through BRI internet banking, Figure 5. 


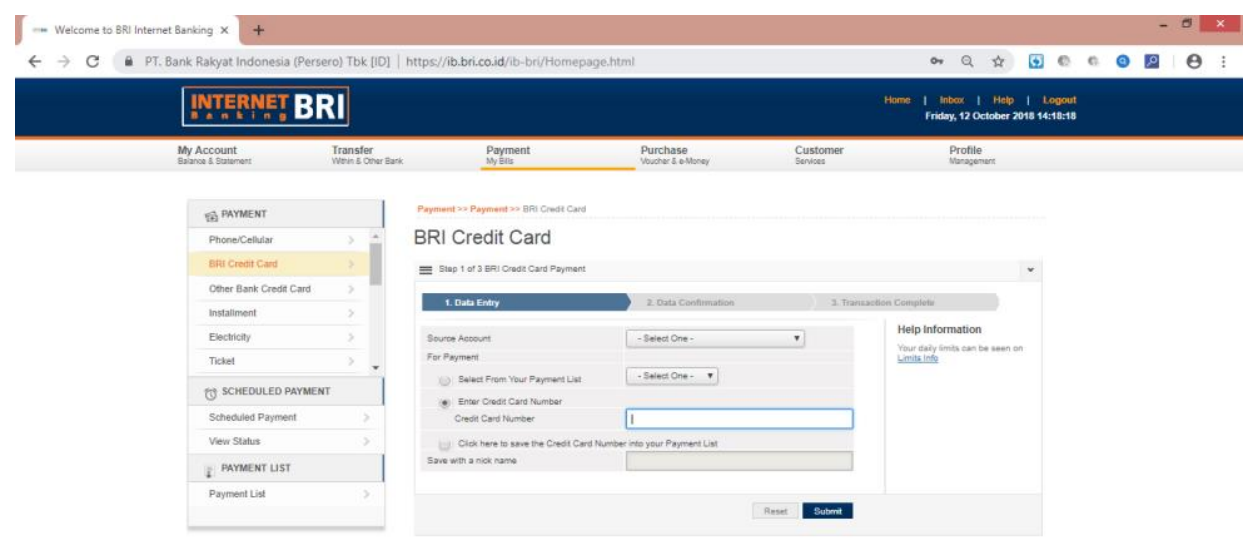

Fig. .5 Payment Menu. Figure was adapted from www.bri.co.id on Dec 10th,2018

The type of payment can be chosen, namely immediate payment, payment on the specified date, regular payment. Bills that can be paid on this facility are bills of Cellphones, Credit Cards, Electricity, Airplane Tickets, State Revenue, Insurance, Subscription Tv, BRIVA, DPLK, BRI Loans, Donations, PDAMs, Multi payment, Education. This will make it easier for e-banking because customers do not bother coming to the bill payment office directly and save the administrative fee. In the Purchase view allows customers to buy electronic money vouchers and deposits can be seen in Figure 6

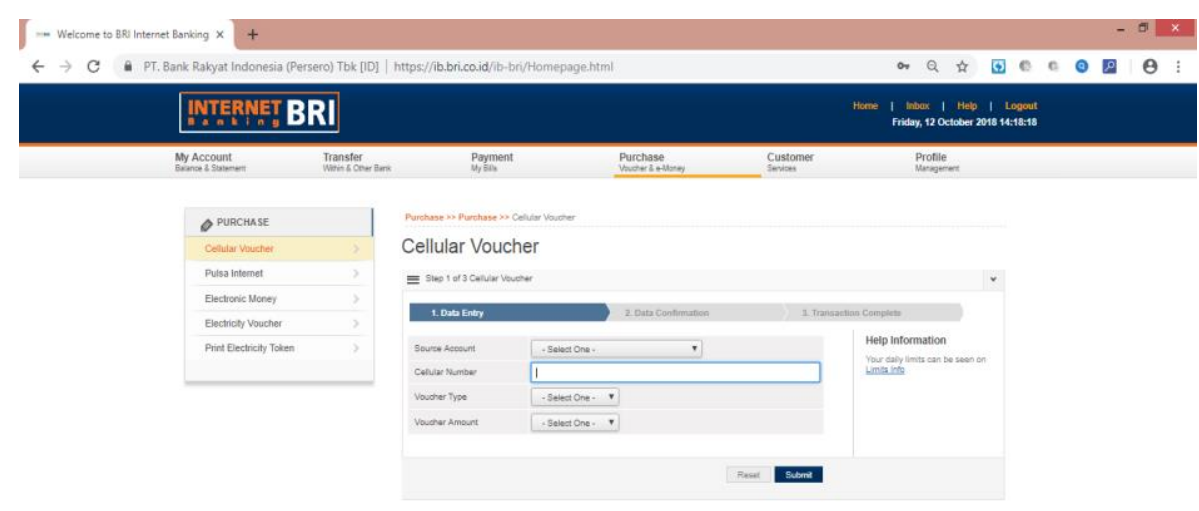

Fig. .6 Purchase Menu. Figure was adapted from www.bri.co.id on Dec 10th,2018 
Customers can also pay for purchases made on the BRI internet banking site. To purchase a cellular phone voucher, the nominal of the voucher will immediately add to the cellular phone credit. In the Customer Service menu, customers can report any complaints to the bank by sending messages via inbox through customer service Figure.7.

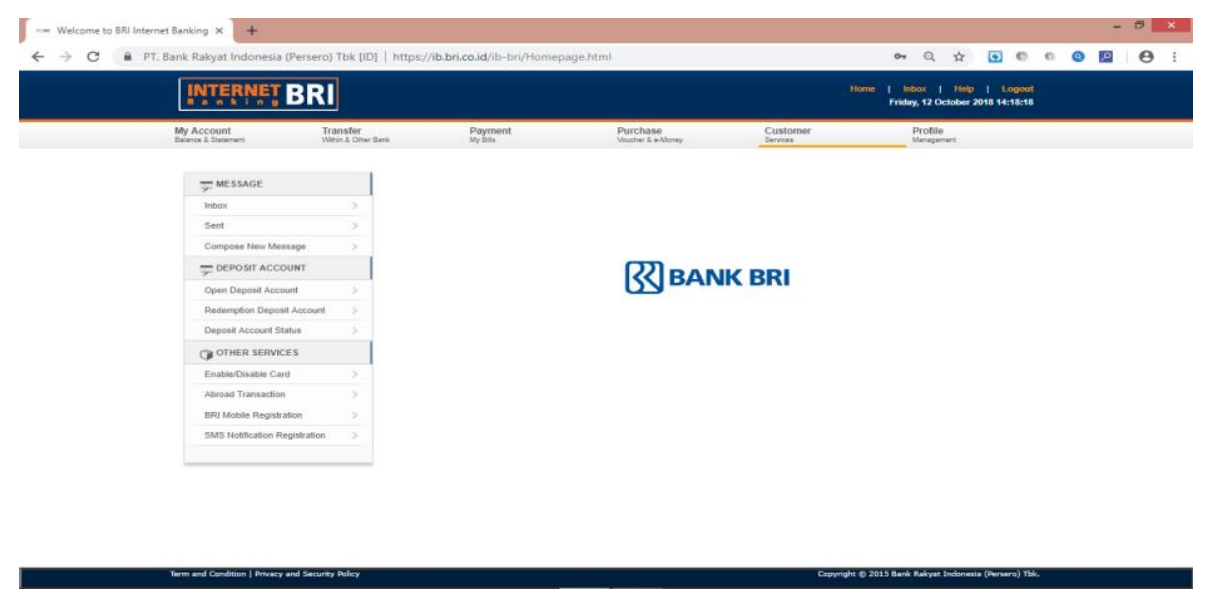

Fig. 7. Customer Service Menu. Figure was adapted from www.bri.co.id on Dec 10th,2018

Customers can also open deposits through internet banking facilities online without having to come directly to the BRI branch. So it can save time and costs spent.

This result is in line with research conducted by Raed Awamleh, and Cedwyn Fernandes that three factors cause customers to use internet banking. The three factors are freedom, comfort, and security. Customers do not need to deal directly with bank employees, and it is a pleasure to use e-banking services that customers can use the service for 24 hours. For security measures, customers have a good perception regarding the safety and reliability of banking services [10].

\section{Conclusion}

Based on the results of the descriptive analysis of the official BRI internet banking, it can be concluded that internet banking is very effective and efficient for the customer. It affects customer' satisfaction variables, security variables, and customer satisfaction are in line. If one of the three does not exist, then customer loyalty will decrease drastically. It will have a fatal impact on the bank.

\section{Acknowledgment}

The authors want to show gratitude to Universitas Komputer Indonesia that has been provided insight and expertise that are very helpful for this research. 


\section{References}

[1] Von Solms, B., \& Von Solms, R.: The 10 deadly sins of information security management. Computers \& Security, 23(5), 371-376 (2004)

[2] Oosterbeek, H., Van Praag, M., \& Ijsselstein, A.: The impact of entrepreneurship education on entrepreneurship skills and motivation. European economic review, 54(3), 442454. (2010)

[3] Duca, J. V.: Financial technology shocks and the case of the missing M2. Journal of Money, Credit, and Banking, 32(4), 820. Akbar, MM \& Parves, M. 2009. Impact Of Service Quality, Trust and Costumer Satisfaction on Costumer Loyalty. ABAB Journal, 29(1): 24-38 (2000)

[4] Akbar, S., Som, A. P. M., Wadood, F., \& Alzaidiyeen, N. J.: Revitalization of service quality to gain customer satisfaction and loyalty. International Journal of Business and Management, 5(6), 113 (2010)

[5] Agpayong,G.K.Q \& Ghana,C.C.: The Effect of Service Quality on Costumer Satisfaction in The Utility Industry-A Case of Vodafone (Ghana). Interntional Journal of Business and Management, 6(5:203-210) (2011)

[6] Rod, M., Ashill, N. J., Shao, J., \& Carruthers, J.: An examination of the relationship between service quality dimensions, overall internet banking service quality and customer satisfaction: A New Zealand study. Marketing Intelligence \& Planning, 27(1), 103-126.Shergill, G. S., \& Li, B. (2005). Internet Banking-An empirical investigation of a trust and loyalty model for New Zealand banks. Journal of Internet commerce, 4(4), 101-118. (2009)

[7] Awamleh, R., \& Fernandes, C.: Internet Banking: An empirical investigation into the extent of adoption by banks and the determinants of customer satisfaction in the United Arab Emirates (2005)

[8] Suh, B., \& Han, I.: Effect of trust on customer acceptance of Internet banking. Electronic Commerce research and applications, 1(3-4), 247-263. (2002)

[9] Alsajjan, B., \& Dennis, C.: Internet banking acceptance model: Cross-market examination. Journal of business research, 63(9-10), 957-963. (2010)

[10] Martins, C., Oliveira, T., \& Popovič, A.: Understanding the Internet banking adoption: A unified theory of acceptance and use of technology and perceived risk application. International Journal of Information Management, 34(1), 1-13. (2014)

[11] Hanafizadeh, P., Keating, B. W., \& Khedmatgozar, H. R.: A systematic review of Internet banking adoption. Telematics and informatics, 31(3), 492-510. (2014) 